\title{
Korean deaths spark inquiry
}

\section{Cases highlight the challenge of policing multinational trade in stem-cell treatments.}

\section{BY DAVID CYRANOSKI IN LOS ANGELES}

$\mathrm{T}$ he controversy over stem-cell tourism, in which patients travel to other countries for unapproved stem-cell treatments, continues to grow. In June, researchers in Thailand reported finding "strange lesions" in a patient who had died following stem-cell therapy for kidney disease (see Nature 465, 997; 2010). And in August, an 18-month-old Romanian boy died after receiving a brain injection of stem cells.

Now South Korea is trying to crack down on the practice. Following the recent deaths of two Koreans who had received injections of stem cells, the Korea Food and Drug Administration and the health ministry last week launched an investigation into companies offering the treatments. But the latest cases highlight the difficulty of policing these therapies or determining their safety, because some companies are setting up operations around the globe, taking advantage of loopholes in other countries' regulations.

One of the companies under scrutiny is Seoul-based RNL Bio, which formulated the cells used to treat the two Korean patients. The firm prepares stem cells at its processing centre in Seoul and sends them to affiliated clinics in China, Japan or elsewhere. Patients travel to these clinics to have the injections, which are illegal in South Korea.

\section{DRUG OR BODY PART?}

In a statement, RNL Bio's chief executive, Ra Jeong-chan, has denied that his company's treatments had anything to do with the deaths. The Korean media are reporting that one patient, a 73-year-old man, died in Japan following a pulmonary embolism; the other failed to wake after receiving an anaesthetic while in China.

Jin Han Hong, president of RNL Life Science, the company's subsidiary in Los Angeles, California, says that the government's investigation will try to determine whether their stem-cell processing in Korea should be banned. "The government wants to define it as a drug and make it illegal," says Hong, who defends the practice: "From our viewpoint it is just part of the patient's body."

Nobuyoshi Tani, head of the regenerative medicine office of the Japanese health

ministry's Research and Development Division, says that companies must gain government approval before they can sell stem-cell therapies in Japan. But Japanese doctors don't need approval to import stem cells for use in their practice.

Last year, China passed regulations that would require stem-cell therapies to pass clinical trials, but there has been much debate about how those rules should be implemented. While the government puts together guidelines, companies such as RNL Bio face an uncertain regulatory situation (see Nature 467, 633; 2010).

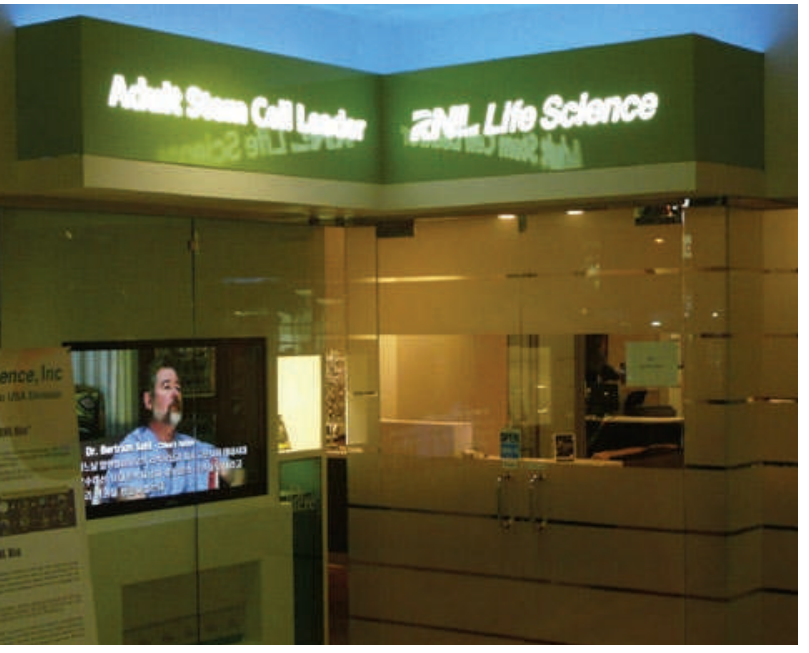

NL Life Science offers patient testimony at its California offices.

received injections of the firm's stem cells. About half have had facial injections, hoping to rejuvenate their appearance, but the company claims that the cells have been used to treat ailments including Parkinson's disease, kidney failure and diabetes.

\section{STEM-CELL BANKING}

Hong admits that there is not yet conclusive clinical-trial evidence that the treatment can help these various conditions, although the company is running trials in South Korea. Asked why RNL would start offering a therapy before it was proven effective, he says that the company offers only stemcell isolation and banking services, not stem-cell therapy. "We don't offer therapy," he says. "It's true that we note the potential but we don't make promises."

But Hong and Shin do talk openly about treatments. Shin, for example, provided details about injection sites and the diseases that could be treated. RNL's patients are recommended to go to affiliated clinics such as the RNL Sunrise Regenerative Medical Center in Yangji, China. And Shin also provided a brochure that describes how a patient recovered from rheumatoid arthritis following treatment. According to the brochure, the patient was "escorted by RNL staff” to the Yangji centre.

RNL Bio hopes to attract more US customers with the opening of RNL Life Science in 2009. Last week Nature visited the office, situated in a shopping mall called Koreatown Galleria, to learn more about the company's products. Jane Shin, whose business card describes her as a "stem-cell consultant", explained that patients visit an affiliated Los Angeles clinic where a plastic surgeon removes about 5 grams of fatty tissue. The sample is sent to the company's Maryland processing centre, where mesenchymal stem cells - which normally regenerate fat, bone or cartilage in the body - are isolated and sent to Seoul to be cultured. Even the simplest stem-cell treatments, such as those for arthritis, require 100 million cells, says Hong. Preparing and banking these cells for three years costs US $\$ 7,500$; every subsequent 100 million cells cost an additional $\$ 5,000$. Standard courses are 600 million cells, says Shin. "The more cells you use, the better you get."

Shin says that 10,000 patients worldwide, including 130 from the United States, have
And looking out from the front window of the Los Angeles office, a wide-screen TV broadcasts testimony of patients happy with the results of the company's services.

Stem-cell scientists contacted by Nature are sceptical about the efficacy of RNL's preparations. "Spontaneous differentiation of adipose-derived stem cells into therapeutic cell types for Parkinson's disease is biologically unrealistic," says Oliver Cooper, director of the Stem Cell Facility at Harvard University's Center for Neuroregeneration Research in Belmont, Massachusetts. Other scientists echoed his sentiments.

Cooper's team hopes to treat Parkinson's with stem cells. But the researchers will implant the cells only after they have differentiated into neurons. Injecting immature stem cells, he says, "does not provide a long-term treatment for Parkinson's disease, and the risk associated with uncontrolled growth of transplanted stem cells is unacceptable". 